\title{
An Empirical Examination of the Relationship between Government Spending and Economic Growth in South Africa, from 1980 to 2011
}

\author{
Letile Gadinabokao1 \\ David Daw2 \\ North West University, Mafikeng, South Africa \\ 1'Letile.Gadinabokao@nwu.ac.za \\ 2David.Daw@nwu.ac.za
}

\section{Doi:10.5901/mjss.2013.v4n3p235}

\begin{abstract}
The paper empirically examines the relationship between government expenditure and economic growth in South Africa, for the period 1980 to 2011. Econometric techniques are applied to test the hypothesis that an increase in government expenditure has increased economic growth. The study examines the causal relationship that exists between government spending and economic growth in South Africa using OLS regression techniques. Secondary data obtained from the SARB is used for data analysis. The results confirm a long-run positive relationship which exists between the two variables under study, and further shows that gross capital formation granger causes economic growth.
\end{abstract}

Keywords: Economic growth, government expenditure, public goods, budget deficit, public debt

\section{Introduction}

This paper examines the specific role that government has played, and continues to play in economic growth in South Africa. As a starting point, we consider that the concept of economic growth is a very important issue to most economists, and decision-makers (Smit et al; 1996). Identifying determinants of long run economic growth remains central to the South African policy debate (Fedderke \& Romm; 2006). According to the authors, numerous contributions have investigated the changing structure of economic growth in South Africa, and addressed the impact of a number of its determinants (Fedderke \& Romm; 2006)

In South Africa, the achievement of long-term economic growth is also a national priority. The size of government expenditures and its effect on long-run economic growth, and vice versa, has been an issue of sustained interest (Loizides \& Vamvoukas; 2005). Economic growth is extremely important because the bottom line for any economy is its ability to satisfy human wants (Van Den Berg; 2001). The rate of economic growth during the nineteenth and twentieth centuries was higher than during any other period of history (Van Den Berg; 2001). According to the author, people's standards of living never improved as much or as rapidly as they did over the past two hundred years. The author adds that, in the last two hundred years, real per capita output in the world suddenly grew eightfold. He suggests that the total value of output produced in the world increased more than forty times (Van Den Berg; 2001). Economic growth is often measured in terms of per capita real income or per capita real output (Van Den Berg; 2001).

In the South African economic system, the general principle has been that the function of the state will be limited to the minimum necessary duties that cannot be done by the community. Originally, the government was not designed to solve economic problems, but to maintain political order (Smit et al; 1996). According to the authors, the fundamental sources of government power is its authority, and not, as in the case of businesses, its material assets. In South African politics, there is an increasing awareness that political desires are limited by economic possibilities, this boundary must be determined before, and not after, decisions are made (Smit et al; 1996).

This study notes that, every government spends money and raises taxes to finance its expenditure (Mohr; 1995). In addition, every government must therefore regularly decide how much to spend, what to spend it on, and how to finance its expenditure. According to the author, governments' must therefore have a policy in respect of the level and composition of government spending and taxation. This is called fiscal policy. Government spending has to be financed in one way or another, and there are three ways of financing government spending - income from property, taxes and 
borrowing. For most of the seventy years since the publication of the General Theory, the phrase 'Keynesian economic policy' has been a synonym for fiscal policy (Mohr; 1995).

In South Africa, the Constitution ${ }^{1}$ is the supreme law of the country. Government functions are derived from the constitution, and are structured according to the constitutional distinction between the legislative, executive, and judicial branches of government, as well as the national, provincial and local levels of government (Black et al; 2008). The South African Constitution contains many provisions that directly or indirectly have an effect upon the extent and composition of government expenditure (Black et al; 2008). According to the authors, these provisions for taxation and government expenditure are basic contours within which budgetary policies of the government is formulated. In South Africa, general government spending includes the outlays of the national government, provincial governments, local authorities, and extra-budgetary institutions, but excludes the spending of public corporations, such as Telkom, Eskom, and Transnet (Black et al; 2008). Looking at the size and growth of general government resources used and the total amount of resource mobilisation using constant 2000 prices, Black et al; 2008, note that this measure suggests that general government expenditure grew significantly in South Africa since 1960 (Black et al; 2008).

In 1960, real per capita government spending in the Republic of South Africa was R 1,703 at constant 2000 prices Alm \& Embaye (2010). The authors points out that by 2007, real per capita spending had more than tripled to R 7,959, and during the same period, real per capita gross domestic product (GDP) increased from R 15,938 to R 25,414 at constant 2000 prices, or by only $60 \%$ (Alm \& Embaye; 2010). Thirty years ago, comparative information on economic growth was limited to a small (and biased) sample of countries, and as more and more countries are brought within the scope of the World Bank's World Development Report, for instance, it has become apparent that middle income countries (of which South Africa is one) can regress economically just as easily as they can progress (Fedderke \&Simkins).Governments and peoples now understand themselves as engaged in the elusive quest for economic growth (Fedderke \& Simkins)

Theoretically, there are two competing school of thought defining this relationship (Tang; 2009). First, Adolf Wagner (1890) postulated that government spending is an endogenous variable and grows faster than income growth. Moreover, government spending is a consequence rather than cause of economic growth. According to the author, Wagner's Law viewed that government spending plays no role in generating economic growth, hence the causality direction runs from economic growth to government spending. However, John Maynard Keynes (1936) argued that government spending is an exogenous variable and used to generate economic growth. For this reason, government spending is a cause rather than effect of economic growth. Therefore, the causal relationship should run from government spending to economic growth (Tang; 2009).

In the 2012 National Budget Speech, The Minister of Finance announced that national spending would exceed R1.1 Trillion for the first time in history (Budget Speech 2012). The Minister outlined that this was about 32\% of GDP. According to the Director General of the National Treasury, Mr. LungileFuzile, this measure was in response to the global recession, and the government hiked its spending to keep South Africa afloat and prevent it from sinking into a deep hole. It is for this reason that this study intends to analyze the relationship between government spending and economic growth in South Africa.

In South Africa, there is growing literature that indicates that the relationship between public expenditure and growth is more complex, and that it is necessary to differentiate between the various components of government expenditure. Studies by (Fedderke; Perkins; \& Luis: 2006) find that investment in infrastructure does appear to lead economic growth in South Africa and does so both directly and indirectly. The results of a study by (Ziramba, 2008) find a long-run relationship between real per capita government expenditure and real per capita income. In addition, causality test results show evidence of bidirectional causality. Therefore, based on empirical results in that study, the author concludes that Wagner's law finds no support in South Africa.

\section{Literature Review}

In a study by (Ansari et al; 1997), three African countries (Ghana, Kenya and South Africa) are chosen for their empirical analysis. The emphasis is on developing countries because of the authors' interests on the role of government expenditure in promoting growth and development. The data used in testing represents annual per capita government expenditure and gross national product (national income) for Ghana (1963-1988), Kenya (1964-1989) and South Africa (1957-1990). The results of the study show that, the Keynesian proposition of government expenditure as a policy instrument to encourage and lead growth in the economy, is not supported by the data for these three African countries.

${ }^{1}$ The Constitution of the Republic of South Africa, Act No 108 of 1996 
Second, in the short run, of the three African countries, only Ghana showed evidence of government expenditure, being caused by national income. In other words, this supports Wagner's hypothesis as to the role of government expenditure as an endogenous factor of economic development (Ansari et al; 1997). And in another study by Dockel \& Seeber (1978), they partially confirmed the relevance of Wagner's law for South Africa (Black et al; 2003). According to the authors, they found high income elasticities for most categories of government spending, which implies that government expenditures 'increase more than proportionally with economic growth'.

The existing empirical studies in general suggest that Wagner's law may hold for developed countries, but less likely so for developing countries (Wu et al; 2010). On the other hand, another strand of literature suggests that government spending could have a positive effect on economic growth if it involves public investment in infrastructure, but could have a negative effect if it involves only government consumption. Yet, previous studies have not reached a consensus on the relationship between government spending and economic growth, owing to their differences in the specification of econometric models, the measurement of government expenditures, and the selection of samples (Wu et al; 2010).

(Alm \& Embaye; 2010), examine the impact of these and other factors on real per capita government spending in South Africa over the 1960-2007 period, starting with a standard median voter model of government spending and extending it to allow for various internal and external shocks. An important part of their estimation strategy is the use of Johansen's $(1988,1995)$ multivariate cointegration technique, which is useful in understanding the relationship between variables that have a unit root (Alm \& Embaye; 2010). This cointegration result lends support to the notion that government spending per capita is associated not only with per capita income and the true cost of government service provision as given by the wage rate but also with the fiscal illusion caused by budget deficits, which make voters discount the true cost of provision of government services. This result also suggests that government spending per capita is not just adjusting to per capita income, but to a long-run equilibrium in which the tax share and the wage rate play a significant role in keeping the relationship stable. The results on Granger causality show clear unidirectional Granger causality from per capita income to government spending per capita. The authors do not find Granger causality running from the tax share and the wage rate to government spending per capita, mainly because of the low power of such tests for cointegrated variables. The fact that these two variables are statistically significant in the cointegration relationship means that it is possible that there might be an indirect Granger causality of these two variables on government spending per capita through per capita income in the Republic South Africa. (Alm \& Embaye; 2010), also find some evidence that government spending per capita was positively affected by external shocks (e.g. war, oil prices). These external shocks seem to play a significant role in explaining the dynamics of government spending per capita growth in South Africa. Internal shocks seem less important factors.

Virtually everyone is in favour of economic growth. However, there are strong disagreements about the best way to accomplish this goal. Some economists and policymakers stress the need to increase capital investment. Others advocate measures to stimulate research, development, and technological change. Still a third group emphasize the role of a better-educated workforce. This leaves us with many stones unturned.

In a South African context, government expenditure is vital, seeing as it is the government that can develop communities, through increased infrastructure projects, and other initiatives, aimed at creating jobs and growing the economy. The question is whether this is a result of market failure to deliver on some goods and services. This though, leaves more questions than answers, as to how we are going to help build a decent life for all the people of South Africa.

\section{Methodology}

This section of the paper introduces the research methodology employed in the analysis of the impact that government spending has on economic growth. The data analysis includes Augmented Dickey-Fuller (ADF) and Phillips Perron (PP) tests for stationarity, as well as employing the use of Johansen and Engle-Granger cointegration tests. An Error Correction Model (ECM) is used to as a way of combining the long-run, cointegration relationship between the levels variables, and the short relationship between the differences of variables. The study also measures causality using the Granger causality test.

\subsection{Data and model}

Theoretical economics may suggest that there is a relationship between two or more variables, but applied economics demands both evidence that this relationship is a real one, observed in everyday life, and quantification of the relationship 
between the variables (Asteriou\& Hall; 2011). According to the authors, economic data sets come in various forms. While some econometric methods can be applied straightforwardly to different types of data set, it is essential to examine the special features of some sets (Asteriou\& Hall; 2011).

The study estimates the relationship between government expenditure and economic growth using the notion, that there is a long-run tendency for the public sector to grow relative to national income or vice-versa. This has been an issue in economics. The study estimates the relationship between economic growth and government expenditure using the following model:

$$
\begin{aligned}
& G D P_{t}=\beta_{0}+\beta_{1} G E X_{t}+e_{t} \\
& G D P_{t}=\beta_{0}+\beta_{1} G E X_{t}+\beta_{2} C A P I_{t}+e_{t}
\end{aligned}
$$

Where $Y_{t}$ is the dependent variable $\beta_{0}, \beta_{1}$, and $\beta_{2}$ are the coefficients or parameters of variables, and $e_{t}$ is a stochastic process. For this study, $Y_{t}$ is the series of gross domestic product (GDP) which is frequently termed economic growth, $\mathrm{GEX}_{t}$ is total general government expenditure, while $\mathrm{CAPI}_{t}$ is gross fixed capital formation by general government on construction works, and $e_{t}$ is the error term. For the purpose of this study, we test both the Engle-Granger technique for our simple two variable model, as well the Johansen cointegration test for our multivariate model.

The study uses time series to examine the relationship between government expenditure and economic growth in South Africa during the period 1980 to 2011. Data for GDP is calculated annually at market prices, and is obtained from the (SARB) website. The data is collected so that estimation can reflect a true value of the series. The data for government expenditure is collected annually using total expenditure by national government. The data collected is secondary data downloaded from the (SARB) South African Reserve Bank, and the study holds no accountability if the data that is downloaded is inadequate

\subsection{Analytical techniques}

For this analysis, prior to estimation of any time series model, the first step is to check the stationarity of variables used as regressors in the model. The aim is to verify whether the series has a stationary trend, and, if non-stationary, to establish orders of integration. Dickey and Fuller $(1979,1981)$ devised a formal procedure to test for non-stationarity (Asteriou\& Hall; 2011).

According to the authors, the test focuses on whether $y=0$. The DF test statistic is the t-statistic for the lagged dependent variable. If the DF statistical value is smaller than the critical value, then the null hypothesis of a unit root is rejected and we conclude that $Y_{t}$ is a stationary process. Dickey and Fuller extended their test procedure by suggesting an augmented version (Augmented Dickey-Fuller - ADF) of the test that includes extra lagged terms of the dependent variable in order to eliminate autocorrelation. The ADF test is given by the following equation:

$$
\Delta Y_{t}=a_{0}+\mathrm{y} Y_{t-1}+a_{2} t+\sum_{i=1}^{p} \beta_{i} \Delta Y_{t-1}+u_{t}
$$

This means that when using ADF methodology, one has to make sure that the error terms are uncorrelated and that they really do have a constant variance (Asteriou\& Hall; 2011). According to the authors, Philips and Perron (1998) developed a generalization of the ADF test procedure that allows for mild assumptions concerning the distribution of errors. The following equation is the test regression for the Philips-Perron (PP) test:

$$
\Delta Y_{t-1}=\alpha_{0}+y Y_{t-1}+e_{t}
$$

While the ADF test corrects for higher-order serial correlation by adding lagged differenced terms on the right hand side, the PP test makes a correction to the t-statistic of the coefficient y from 3 (equation 3 ) to account for the serial correlation in et. So in essence, the PP statistics are only modifications of the ADF t-statistic that take into account the less restrictive nature of the error process. Just like the ADF test, the PP test can be performed with the inclusion of a constant, a constant and a linear trend, or neither in the test regression.

Another important element in the formulation of a dynamic model is determining whether an intercept and/or trend should enter the short-run or the long-run model; represented by the following equation:

$$
\Delta Z_{t}=\Gamma_{1} \Delta Z_{t-1}+\ldots+\Gamma_{k-1} \Delta Z_{t-k-1}+\alpha\left(\beta Z_{t-1} \mu_{1} 1 \delta_{1} t\right)+\mu_{2}+\delta_{2} t+u_{t}
$$

We determine the rank of $\Pi$, or the number of cointegrating vectors, and then we test for weak exogeneity. Lastly, we test for linear restrictions in the cointegrating vectors, for long run parameters for prediction.

Economists are mainly interested in long-run relationships, and therefore the concept of cointegration and the ECM are very useful to resolve this. What is of importance is that when two variables $Y$ and $X$ are cointegrated, the ECM incorporates not only short-run, but also long-run effects. This is because the long-run equilibrium is included in the model, together with the short-run dynamics captured by the differenced data. The ECM model is represented by the following equation: 
$\Delta G D P_{t}=\mu+\sum_{i=1}^{n-1}$ ai $\Delta G D P_{t-1}+\sum_{i=0}^{m-1} y i \Delta G E X_{t-1}-\pi \hat{e}_{t-1}+\varepsilon_{t}$

Where $\pi$ is the error-correction coefficient and/or the adjustment coefficient, and $\varepsilon_{t}$ is our equilibrium error. $\pi$, tells us how much of the adjustment to equilibrium takes place in each period, or how much of the equilibrium error is corrected. The level terms of $\mathrm{GDP}_{\mathrm{t}}$ and $\mathrm{GEX}_{\mathrm{t}}$ in the $\mathrm{ECM}$ tells us exclusively about the long-run parameters of the two variables. Equation (5) is the ECM representation, it allows us to use both long-run information, and short-run disequilibrium dynamics which are very useful for our analysis, and this is a very important feature of the ECM.

The Granger causality test for two stationary variables $\mathrm{GDP}_{\mathrm{t}}$ and $\mathrm{GEX}_{\mathrm{t}}$ involves the estimation of the following VAR model:

$$
\begin{aligned}
& G D P_{t}=a_{1}+\sum_{i=1}^{n} \beta i G E X_{t-1}+\sum_{j=1}^{m} y j G D P_{t-j}+e_{1 t} \\
& G E X_{t}=a_{2}+\sum_{i=1}^{n} \theta i G E X_{t-1}+\sum_{j=1}^{m} \delta j G D P_{t-j}+e_{2 t}
\end{aligned}
$$

The first thing to do is to estimate the VAR model given by equations (6) and (7). From then on, we check the significance of the coefficients, and apply variable deletion tests. Depending on the results of the variable deletion tests, we conclude about the direction of causality. One way of detecting misspecification problems is by observing regression residuals (Asteriou\& Hall; 2011).

\section{Analysis of Results}

This section presents all the results of testing the fiscal-policy-growth nexus, for the period 1980 to 2011 . The interpretation and analysis is with regard to the relationship between government spending and economic growth. Data obtained from the SARB (South African Reserve Bank) is analyzed and treated using the following tools and techniques, namely, unit root tests depicted by, ADF unit root tests, and tests for cointegration and ADF test on residuals. A great deal can be learnt from a preliminary analysis of the data

\subsection{Unit root test results}

ADF unit root test is performed in order to take out the non-stationarity in the series. In this section, we perform the ADF unit root test at levels and at first difference. Using the lags, we find the significance level at trend, trend and intercept, and none.

The results from the test (in Table 1) indicate clearly that the null hypothesis (non-stationarity) cannot be rejected for most of the variables, when the test is run in levels (at trend, at trend and intercept, and none). At this point of our analysis, we employ differencing in order to observe whether the series will exhibit a stationary trend.

As can be seen in Table 1, most of the variables are significant at 1 percent, 5 percent, and 10 percent. We therefore reject the null hypothesis, that of non-stationarity, against the alternative. It is clear from our examination that the variables are stationary, which means that their mean and variance are constant. Table 1 presents the results of the ADF Unit Root tests which formally confirm the stationarity of the variables under study. This can be observed by the many 'star signs/asterix' assigned to the ADF, which indicate the significance levels.

\begin{tabular}{|c|c|c|c|c|c|c|c|c|c|}
\hline \multicolumn{10}{|c|}{ ADF Unit Root Test for all variables at levels } \\
\hline $\begin{array}{l}\text { Series } \\
\text { Levels }\end{array}$ & Model & $\begin{array}{l}\text { Lag } \\
\text { Length }\end{array}$ & ADF & ADF & $\begin{array}{l}\text { Series } \\
\text { Levels }\end{array}$ & Model & $\begin{array}{l}\text { Lag } \\
\text { Length }\end{array}$ & $\begin{array}{l}\text { PP Test- } \\
\text { statistic }\end{array}$ & $\begin{array}{l}\text { Critical } \\
\text { Value }\end{array}$ \\
\hline \multirow[t]{3}{*}{ GEX } & Intercept & 1 & $-6.1289^{\star \star \star}$ & $-3.6852^{\star \star \star}$ & GEX & Intercept & 2 & $-18.2782^{\star \star \star}$ & $-3.6752^{\star \star \star}$ \\
\hline & $\begin{array}{|ll|}\text { Trend } & + \\
\text { Intercept }\end{array}$ & 2 & $-5.7393^{\star *}$ & $-4.3382^{* *}$ & & $\begin{array}{l}\text { Trend + } \\
\text { Intercept }\end{array}$ & 2 & $-17.9222^{\star \star *}$ & $-4.3082^{\star \star \star}$ \\
\hline & None & 2 & $-5.9855^{\star \star \star}$ & $-2.6522^{\star \star *}$ & & None & 2 & 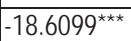 & $-2.6453^{\star \star \star}$ \\
\hline \multirow[t]{3}{*}{ GDP } & Intercept & 1 & $-4.5123^{\star *}$ & $-3.6852^{\star *}$ & GDP & Intercept & 1 & $-7.9366^{\star \star}$ & $-3.6752^{\star *}$ \\
\hline & \begin{tabular}{|l|}
$\begin{array}{l}\text { Trend } \\
\text { Intercept }\end{array}$ \\
\end{tabular} & 1 & $-4.4134^{\star \star}$ & $-4.3226 * \star$ & & $\begin{array}{l}\text { Trend + } \\
\text { Intercept }\end{array}$ & 1 & -7.7949 ** & $-4.3082^{\star *}$ \\
\hline & None & 2 & $-4.3459^{\star \star}$ & $-2.6522^{\star *}$ & & None & 1 & $-8.0668^{\star \star}$ & $-2.6453^{\star \star}$ \\
\hline \multirow[t]{3}{*}{ CAPI } & Intercept & 2 & $-5.5509^{\star \star *}$ & 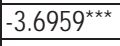 & CAPI & Intercept & 1 & $-9.6794^{\star \star \star}$ & $-3.6752^{\star \star \star}$ \\
\hline & \begin{tabular}{|l|}
$\begin{array}{l}\text { Trend } \\
\text { Intercept }\end{array}$ \\
\end{tabular} & 1 & $-5.8064 * \star *$ & -4.3226 *** & & $\begin{array}{l}\text { Trend + } \\
\text { Intercept }\end{array}$ & 1 & $-9.4887^{\star *}$ & $-4.3082^{\star *}$ \\
\hline & None & 2 & $-5.6405^{\star \star \star}$ & $-2.6522^{\star \star \star}$ & & None & 1 & $-9.8673^{\star \star \star}$ & $-2.6453^{\star \star \star}$ \\
\hline
\end{tabular}

\section{Table 1.}

*- Statistically significant at 10\% level, **- Statistically significant at 5\% level, ***-Statistically significant at 1\% level 
The results of the Philips-Perron unit root test, suggest that the variables are integrated of order one. Evidence indicates that the series under study are stationary in the first difference. Therefore, most of the variables reject the null hypothesis of non-stationarity at a significance level of 1 percent and 5 percent, against the alternative. This implies that there is a possibility of a long run relationship between the variables.

\subsection{Cointegration results}

If the variables are not cointegrated, we have problems of spurious regression and econometric work becomes meaningless. On the other hand, if the stochastic trends cancel, then we have cointegration. The study employs a conventional OLS method for cointegration testing. The estimate equation is run at levels in order to obtain the residuals, which are then tested for stationarity. If the coefficient has a negative sign, this means that a negative relationship exists between the variables under investigation. This is demonstrated below in Table 2, where the coefficient has a negative sign. We analyzed 32 observations using time series regression for the period between 1980 and 2011 in South Africa. The results indicate that government expenditure has a coefficient of -1.43 , which indicates that a negative relationship exists between the two variables. The $R^{2}$ is 0.22 , and this implies that there is a 22 percent chance that government expenditure will impact negatively on economic growth in the short run.Unit root testing on residuals (RESID01) shows that the ADF for constant + trend are significant at the 5 percent and 10 percent levels. Therefore, we reject $H_{0}$, which means that the residuals are stationary, and therefore there is cointegration.

\subsubsection{Johansen cointegration test results}

The study confirms cointegration by employing the Johansen Cointegration technique. According to the critical values reported by Johansen cointegration, a likelihood ratio, and Eigenvalue test statistics provided significant evidence for the existence of a cointegrating relationship between total government expenditure by national government, gross fixed capital formation, and GDP growth. The cointegration exists with 2 (two) cointegrating vectors.

\subsection{Error Correction Model (ECM) Results}

We observed that the coefficient on total government expenditure, and gross capital formation by government in construction works is negative and statistically insignificant in the short run. According to the results, expenditure by the government on construction works and on other expenditures does not affect GDP in the short-term. The coefficient for government expenditure is insignificant and shows $(-0.021)$, and the coefficient for gross capital formation is also insignificant and has almost the same magnitude $(-0.020)$, as that of government expenditure. This means that in the short-run, both gross capital formation and government spending, show no evidence indicating any significance of these variables explaining GDP growth. The estimated coefficient on the cointegration regression residual $\operatorname{ECM}(-1)$, is negative as it should be.

The results indicate that the coefficient on total expenditure by national government is positive and statistically significant in the long-run, suggesting that increased government expenditures will boost economic growth in the long run. However, it can be observed that gross capital formation affects growth negatively in the long-run. These variables are statistically significant at 1 percent and 5 percent in explaining GDP growth. From a statistical point of view, it appears as though we have a moderately good relationship with approximately 58 percent of the variation in the dependent variable being explained by the regressors. In summary, there is sufficient evidence to show that in the short-run, both gross capital formation by government, and total expenditure by national government do not influence economic growth. In the long-run, however, we observe that government expenditures has a small positive and significant effect on economic growth.

\subsection{Granger Causality Results}

The results of the Granger causality test indicate that in almost all the cases, the reported probabilities are greater than 0.05 significance levels. No evidence is found to suggest that government expenditure Granger causes GDP. There is also no evidence to suggest that gross capital formation Granger causes GDP. In testing for Granger causality, the study employed 2 lags. The hypothesis that GDP does not Granger cause gross capital formation is rejected at 5 percent significance levels. The evidence in this section does not provide much support for the causality relationship between 
government expenditure and economic growth. There is weak evidence that suggests that causality runs from GDP to government spending. On the other hand, there is sufficient evidence to suggest that gross capital formation by government in construction works granger causes economic growth.

\subsection{Diagnostic test results}

The results of the diagnostic tests above show a Jacque-Bera value of 1.618 with a corresponding $p$-value of 0.445 confirming that the residuals are normally distributed. The Breusch-Godfrey test results indicate that there is no serial correlation in the residuals up to the 2 nd order. The results conclude that there is no autoregressive conditional heteroskedasticity, and therefore accepts the null hypothesis. The test shows that our model is stable and conforms to CLRM assumptions.

\section{Summary of Results}

The results of unit root testing reject the null hypothesis of non-stationarity, and confirm that the variables are stationary after differencing at the first level and integrated of the first order.

The results of the Engle-Granger test indicate that there is a negative relationship between economic growth and government expenditure in the short run. Unit root testing on residuals (RESID01) shows that the ADF for constant + trend are significant at the 5 percent and 10 percent levels. Hence, we reject $\mathrm{HO}$, which means that the residuals are stationary, and as a result, there is cointegration. The study confirms cointegration by also employing the Johansen Cointegration technique. According to the critical values reported by Johansen cointegration, the results provide significant evidence for the existence of a cointegrating relationship between total government expenditure by national government, gross fixed capital formation, and GDP growth. The cointegration exists with two cointegrating vectors. Thus, we reject the null hypothesis.

The results of estimating the ECM, reveal sufficient evidence to explain that in the short-run, both gross capital formation by government, and total expenditure by national government do not influence economic growth. Whereas, in the long-run, we observe that government expenditures has a small positive and significant effect on economic growth. This result is extremely important for our analysis. The results show that a negative relationship exists between public expenditure and economic growth in the short-run. The results also indicate that the coefficient on total expenditure by national government is positive and statistically significant in the long-run, suggesting that increased government expenditures will boost economic growth in the long run.

Granger causality tests do not shed light on the direction of causality between public expenditure and economic growth. There is weak evidence to suggest causality in any direction. However, there is sufficient evidence to suggest that gross capital formation by government in construction works granger causes economic growth. This means that investment in construction works by national government causes economic growth. The results of the diagnostic and stability checks provide us with important information related to the stability of our model.

\section{Conclusion and Policy Recommendations}

The results of the causality tests offer, little to no support for Wagner's Law, although a small positive increase is achieved. The study notes that this result suggests that increased government will boost economic growth. If economic growth increases, it follows that per capita GDP will also increases. With an increase in per capita GDP, real incomes will rise, and because of increased real incomes, disposable incomes will increase. This will create an enabling environment, which leads to a rise in living standards. This will increase individual wellbeing and benefit all participants in the economy. In conclusion, the findings are consistent with current research literature. The results show that the South African government needs to spend more money on infrastructure programmes, which are mostly aimed at job creation, since they are more ideal for making the economy grow. According to the results of this analysis, initiatives aimed at growing the economy through infrastructure projects are essential both in the short-run, because the impact on growth is minimal, as well as in the long-run, where its impact is greater. This means that the South African government is justified in the prioritisation of infrastructure development programs. Research on productive government expenditure will enhance the current literature in the area of public finance. 


\section{References}

Abedian, I. \& Biggs, M., (1998) Economic Globalization and Fiscal Policy, Cape Town, Oxford University Press

Akitoby, B., Clements, B., Gupta, S., Inchauste, G., (2006) Public Spending, Voracity, and Wagner's law in developing countries, European Journal of Political Economy 22 (2006) 908-924

Alexiou, C., (2009) Government Spending and Economic Growth: Econometric Evidence from the South Eastern Europe, Journal of Economic and Social Research 11(1) 2009, 1-16

Alm, J., \& Embaye, A., (2010) Explaining the growth of government spending in South Africa, Economic Society of South Africa, South African Journal of Economics, Vol. 78:2

Ansari, M.I., Gordon, D.V., Akuamoah, C., (1997) Keynes versus Wagner: Public expenditure and national income for three African countries, Routledge, Mortimer Street, London

Asteriou, D., \& Hall, S.G., (2011), Applied Econometrics, Second Edition, Palgrave Macmillan, Macmillan Publishers Limited, Basingstoke, Hampshire

Barro, R.J., (1988) Government spending in a simple model of endogenous growth, NBER Working Paper No 2588, 1050 Massachusetts Avenue, Cambridge

Black, P.A., Calitz, E., Steenkamp, T.J., and Associates (2003) Public Economics for South African Students, Second Edition, Oxford University Press

Cameron, N., (2003) Physical growth in a transitional economy: The aftermath of South African apartheid, Economics and Human Biology, Elsevier Science BV, elsevier.com

Du Plessis, S., Smit, B., (2006) Economic growth in South Africa since 1994, Bureau for Economic Research (BER), Stellenbosch Economic Working Papers: 1/2006

Fedderke, J., Perkins, P., Luis, J., (2006) Infrastructural investment in long-run economic growth: South Africa 1875-2001, World Development, Volume 34, Issue 6, June 2006, Pages 1037-1059

Fedderke, J.W., Bogetic, Z., (2009) Infrastructure and growth in South Africa: Direct and indirect productivity impacts of 19 infrastructure measures, World Development, Volume 37, No 9, 1522-1539

Fedderke, J.W., Simkins, C., (2009) Economic growth in South Africa since the late nineteenth century, Working Papers 138, Economic Research South Africa

Fourie, C.V.N., (1999) How to think and reason in Macroeconomics: Second Edition, Juta\& Co. Ltd, Kenwyn 7790, (1- 386)

Fourie, J., (2006) Economic Infrastructure - A review of definitions, theory and empirics, South African Journal of Economics, 74: 530556

Frankel, J., Smit, B., Sturzenegger, F., (2008) South Africa: Macroeconomic challenges after a decade of success, Blackwell Publishing, Economics of Transition, Volume 16(4) 2008, 639-677

Ghura, D., (1995) Effects of Macroeconomic Policies on Income Growth, Inflation, and Output Growth in Sub-Saharan Africa, Journal of Policy Modelling, Society for Policy Modelling, North Holland, 1995 (397-395)

Habib; A., Padayachee, V., (2000) Economic Policy and Power Relations in South Africa's Transition to Democracy, World Development, Volume 28, No 2 pp 245-263

Loizides, J., \& Vamvoukas, G., ( 2005) Government expenditure and economic growth: evidence from trivariate causality testing, Journal of Applied Economics, Vol. VIII, No. 1, 125-152

Mohr, P., Fourie, L., \& Associates (2004) Economics for South African Students 3rd edition, Van Schaik Publishers, 1064 Arcadia Street, Hatfield, Pretoria

Musgrave, R.A., Peacock, A., (1967) Classics in the Theory of Public Finance: Three extracts on public finance by Adolf Wagner, International Economic Association Publications, Macmillan

Nketiah-Amponsah, E., (2009) Public spending and economic growth: Evidence from Ghana, Routledge, Development Southern Africa, Volume 26 , No 3

Samuelson, P. \&Nordhaus, W. (1995) Economics: fifteenth edition, Irwin McGraw-Hill, Boston, Massachusetts

Smit, P., Dams, D., Mostert, J., Oosthuizen, A., Van Der Vyver, T., Van Gass, W., (1996), Economics: A Southern African perspective, Juta\& Co Ltd, Kenwyn

Van Rensburg, J.J., McConnell, C.R., Brue, S.L., (2011) Economics: Southern African Edition; 2011; McGraw-Hill Higher Education

Ziramba, E., (2008) Wagner's Law: An econometric test for South Africa 1960-2006, Blackwell Publishing, South African Journal of Economics, Volume 76:4 596-606 